\title{
Investigation of the Acid Strength Effects on Bipolar Membrane Electrodialysis
}

\author{
Jülide Erkmen ${ }^{1, *}$ and Sinan Yapici ${ }^{2}$ \\ ${ }^{1}$ Chemical Engineering Department, Engineering Faculty, Kafkas University, Kars 36300, Turkey \\ ${ }^{2}$ Chemical Engineering Department, Engineering Faculty, Atatürk University, Erzurum 25240, Turkey
}

\begin{abstract}
The purpose of this paper is to investigate acid strength effects on the same system for production of two different acids. Production of two different acids from their salts was carried out by electro dialysis (ED) using bipolar membranes (BPM). An virulent acid hydrofluoric acid and an weak acid boric acid were produced, all data were recorded and compared. Result of the study, in electro dialysis of acids and base, acid strength play an important role in terms of the efficiency of the process. Current efficiency was calculated very high at all processes for this electro dialysis (EDBM) system. This results in a growing demand for alternative process solutions such as Electro dialysis with Bipolar Membranes (EDBM).
\end{abstract}

Keywords: Bipolar Membrane, Ion Migration, Current, Acid Strength.

\section{INTRODUCTION}

Bipolar membrane electro dialysis (EDBM) is a technology used for the production of protons and hydroxyl ions [1] widely studied and applied for a multitude of technical applications, amongst them the production of organic acids [2-12], in environmental applications such as waste water treatment [13-16] or carbon dioxide recovery [17] and in the food industry $[18,19]$. A bipolar membrane consists of an anion Exchange layer (positively charged) and a cation Exchange layer (negatively charged). At the interface of both layers, water splitting takes place. $\mathrm{H}+$ that migrates through the cation Exchange membrane towards the cathode and $\mathrm{OH}^{-}$that migrates through the anion exchange membrane towards the anode are produced. Overall, at the anode side an alkaline solutions formed and an acidic solution appears at the cathode side [1]. At the same time due to the nature of the membrane, the transport of ions across the bipolar membrane is prevented. This concept can be used to control the $\mathrm{pH}$ in electro- dialysis applications and is called BPM-ED.

Until today synthesis of the acid-base from salt was examined in many bipolar membrane processes at different membrane types and in different configurations. For example BMED was studied to regenerate concentrated organic and inorganic acids such as acetic acid [20], gluconic acid [21], citric acid [26], lactic acid [22] or phosphoric acid [23]. Only few papers were published concerning electro dialysis of

*Address correspondence to this author at the Chemical Engineering Department, Engineering Faculty, Kafkas University, Kars 36300, Turkey;

E-mail: jerkmen@hotmail.com formic acid (26). Luo et al. [24] and Nagarale et al. [25] demonstrate the feasibility of ED in order to concentrate formic acid solution. Current efficiency is generally taken as the first criterion of the electro dialysis performance. When performing electro dialysis of organic acids the molecular acid diffusion contribution to reduce the current efficiency was underlined by several authors like those referenced [21-28]. Several studies have shown that the ED process, involving bipolar membranes, have economic potential for recovering inorganic, organic or amino acids [29]. But in the same process, effects of different two acids on the system were not investigated. The purpose of this paper is determined, that during the production of different two acids changes in the same process.

In this study, the virulent acid hydrofluoric acid from sodium fluoride and weak acid boric acid from borax was produced. All data were recorded and compared during the production of these acids.

\section{EXPERIMENTAL}

\subsection{Materials}

Chemicals Borax $\left(\mathrm{Na}_{2} \mathrm{~B}_{4} \mathrm{O}_{7} \cdot 10 \mathrm{H}_{2} \mathrm{O}\right), \mathrm{H}_{2} \mathrm{SO}_{4}, \mathrm{H}_{3} \mathrm{BO}_{3}$, $\mathrm{NaOH}$, Carmine indicator, $\mathrm{NaF}, \mathrm{HF}, \mathrm{NaOH}$ and TiSAB III (total ionic strength adjustment buffer) used in the experiments and analysis were purchased from MERCK. Ion-exchange membranes and bipolar membranes used in the electrochemical cell were purchased from PCA GmbH Table 1. Illustrates the main characteristics of the commercial ED membranes used in this study. 
Table 1: Main Characteristics of Membranes Used in this Work

\begin{tabular}{|c|c|c|}
\hline \multirow{2}{*}{ Manufacturer } & PCA GmbH & PCA GmbH \\
\hline & PC acid 60 & PC SK \\
\hline $\begin{array}{l}\text { Transference number } \\
\qquad \mathrm{KCl}(0.1 / 0.5 \mathrm{~N})^{\mathrm{a}} \\
\text { Acid }(0.7 / 3 \mathrm{~N})^{\mathrm{b}}\end{array}$ & $\begin{array}{c}>0.95 \\
55\end{array}$ & $>0,95$ \\
\hline Resistance / $\Omega . \mathrm{cm}^{2}$ & $\sim 2$ & $\sim 2.5$ \\
\hline Water content (wt\%) & $\sim 17$ & $\sim 9$ \\
\hline $\begin{array}{c}\text { Ion exch. capacity } \\
\text { Strong basic (meq.g-1): } \\
\text { Weak basic (meq.g-1): }\end{array}$ & $\begin{array}{l}\text { ca } 1.14 \\
\text { ca } 0.45\end{array}$ & $\mathrm{n} / \mathrm{a}$ \\
\hline
\end{tabular}

${ }^{a}$ Calculated from potentiometric measurements.

${ }^{\mathrm{b}}$ Observed current efficiencies.

The experimental cell was composed of nine membranes. This cell included three paces of three compartments (salt, acid and base compartment). Each of the membranes has $64 \mathrm{~cm}^{2}$ surface areas. The cathode is stainless steel and the anode is Pt/lr alloy coated by titanium in ED cell. A scheme of the experimental set-up is illustrated in Figure 1. In all compartments, solutions were circulated in a batch mode using centrifugal pumps.

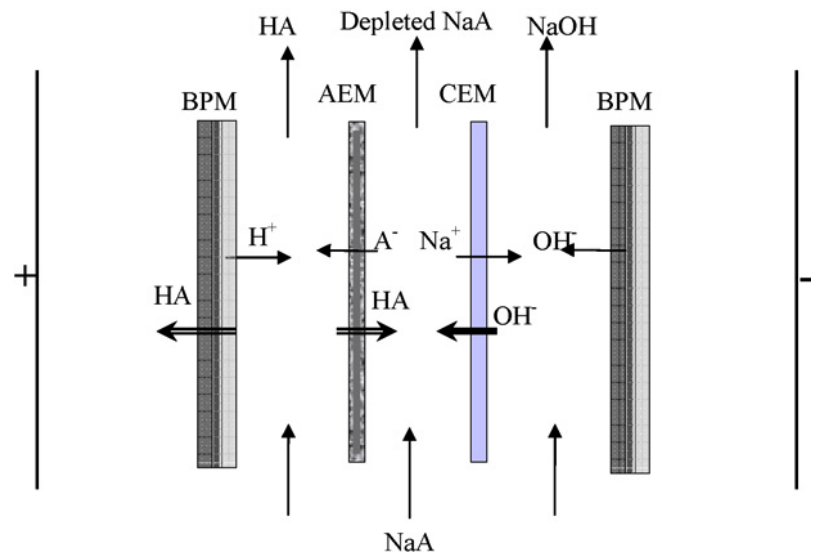

Figure 1: Principles of bipolar membrane electro dialysis and mass fluxes [30].

The streams containing acid, base and its salt solution were held at constant temperature $\left(25^{\circ} \mathrm{C}\right)$ with a thermostatic controlled constant temperature water circulator and the serpentines located in each compartment. The changes in concentration of different solutions circulating in the ED unit were measured by samples from the each solution at regular time intervals. The needed constant voltage to the cell was supplied by digital controlled D.C. power supply.

\subsection{Methods}

The initial compositions of the solutions in each compartment were the following:
- 1 liter $\mathrm{NaF}$ solution in the salt compartment

- 1 liter $0,1.10^{-5} \mathrm{M} \mathrm{NaOH}$ solution in the base compartment

- 1 liter $0,1.10^{-5} \mathrm{M}$ HF solution in the acid compartment

In this study, the values of chosen parameters were determined as follows: The values of initial $\mathrm{NaF}$ concentrations are of $0.025 \mathrm{M}$ and $0.05 \mathrm{M}$, applied potential values of $5 \mathrm{~V}, 7.5 \mathrm{~V}$, and $10 \mathrm{~V}$. The solution flow rate is of $0.381 / \mathrm{min}$ in all experiments.

The analysis of fluorine was performed by Metler Toledo multi meter, analysis of sodium monitored by flame photometer (Sherwood 410) and analysis of boron was performed by carmine method and was monitored by UV spectrophotometer (Mapada V-1100) at wavelength of $585 \mathrm{~nm}$.

\section{RESULTS AND DISCUSSION}

The current-time curves for the two acids were given at Figures 2-3 Molar flux was defined as the amount of transition mol in unit of time from unit membrane area. If ion concentration decreases, the amount of substance decreases from unit membrane area. It can be seen clearly at Figures 3-4 from HF 10V curve.

For the maximum voltage $10 \mathrm{~V}$, the current-time curve was shown at the Figure 4. The transport process of salts through the membrane is diffusion controlled and depends on the hydrodynamic of system [31]. The selectivity of the membrane is dependent on concentration of fixed charge, concentric to the valence of the ions, to the valence of the counter ion and concentration of the electrolyte solution [32]. Hence, 


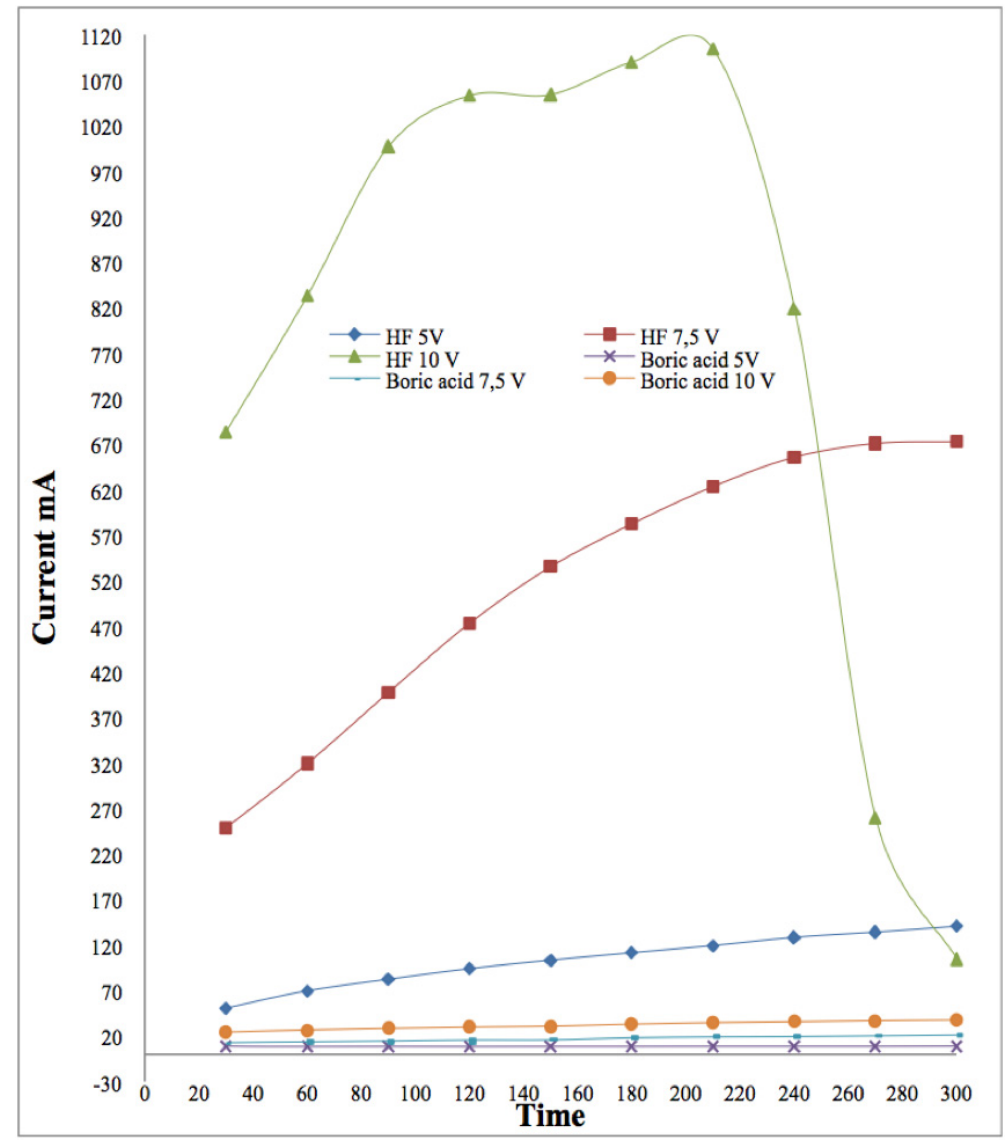

Figure 2: Current-Time curves comparison of systems at $0.025 \mathrm{M} \mathrm{HF}$ and $0.025 \mathrm{M} \mathrm{H}_{3} \mathrm{BO}_{3}$ starting concentration.

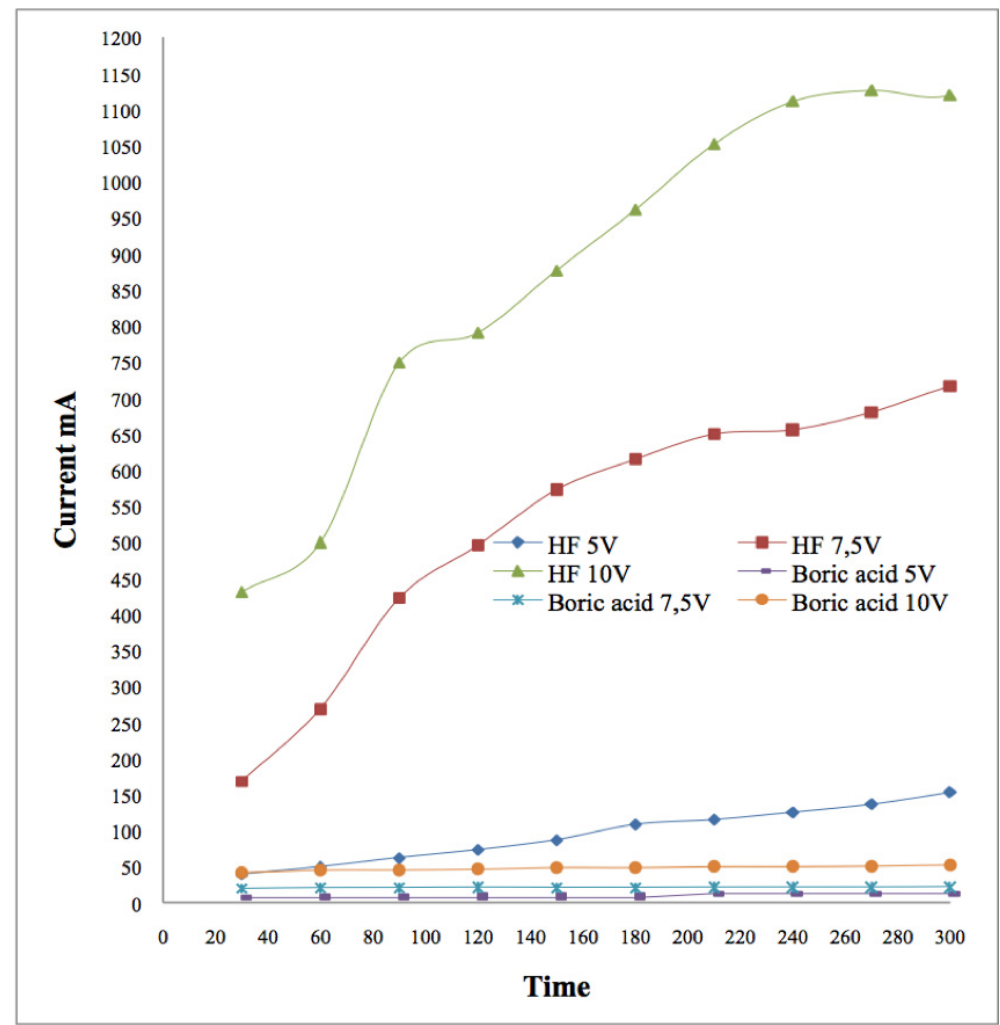

Figure 3: Current-Time curves comparison of systems at $0.05 \mathrm{M} \mathrm{HF}$ and $0.05 \mathrm{M} \mathrm{H}_{3} \mathrm{BO}_{3}$ starting concentration. 


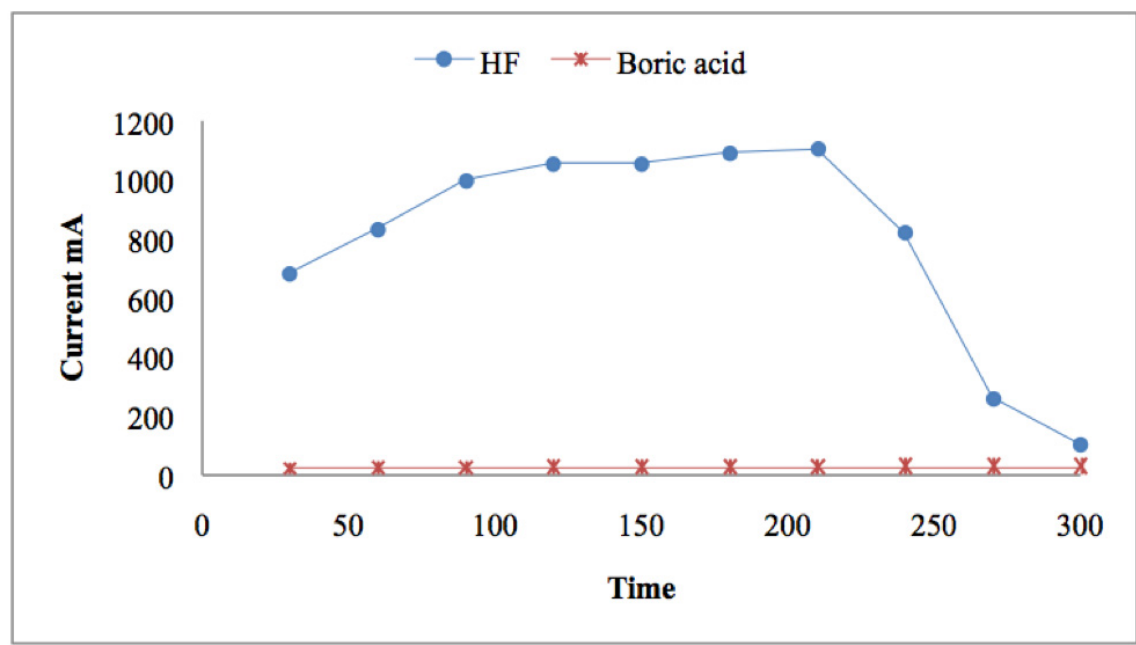

Figure 4: Current-Time curves comparison of systems at $0.025 \mathrm{M} \mathrm{HF}$ and $0.025 \mathrm{M} \mathrm{H}_{3} \mathrm{BO}_{3}$ starting concentration, $10 \mathrm{~V}$ operating voltage and $0,38 \mathrm{l} / \mathrm{min}$ flow rate.

when looking at test results under the employed conditions and used system in this study, it can be seen easily the rate of production acid and base increases with increasing concentration.

However, membranes were damaged at high concentration and high voltage. As shown in Figures 56 for HF at $0.05 \mathrm{M}$ concentration and $12.5 \mathrm{~V}$ applications, it was observed that due to excessive current density, membranes were seriously damaged.
In electro dialysis of acids, $\mathrm{pH}$ changes play an important role in terms of the efficiency of the process [33]. The change in the moles numbers of HF was more impressed to $\mathrm{pH}$. Therefore, at the low voltage of the HF production rate was greater than the boric acid production rate.

At preliminary experiments made for this study, because of the strength of both acids, the effects of acids on membrane was found to be different. While at

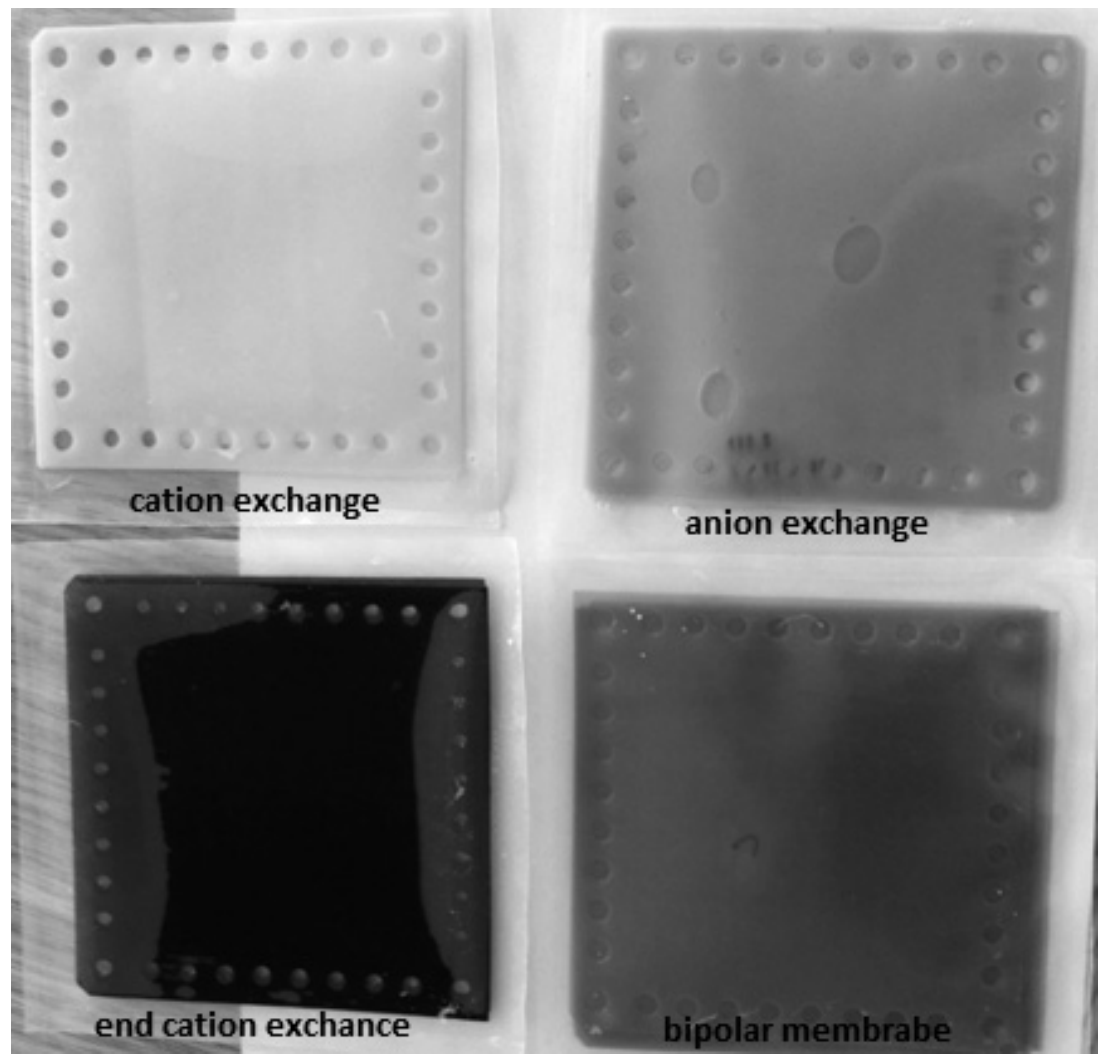

Figure 5: New membranes. 


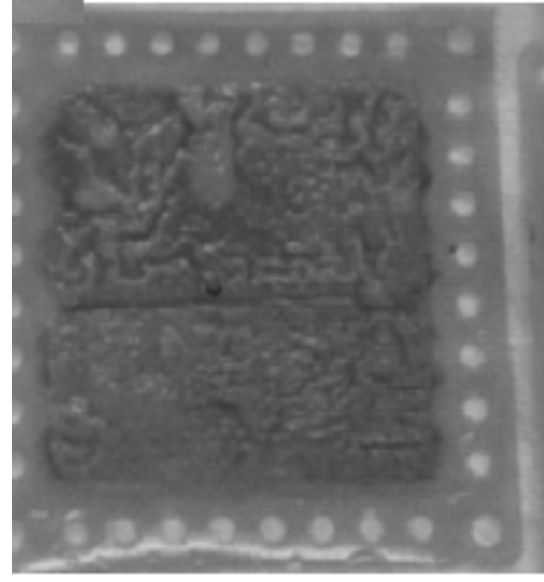

a) Bipolar membrane

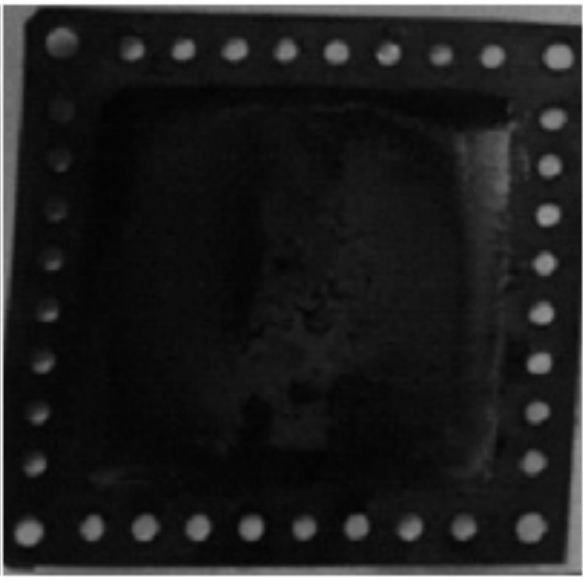

b) Katyon exchange end membrane

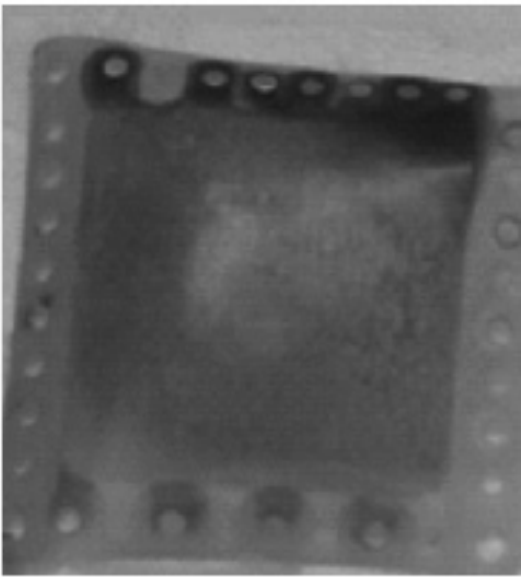

c) Anyon Exchange membrane

Figure 6: Damaged membranes.

Table 2: Current Efficiency All Operations at End of 300 Minute

\begin{tabular}{|c|c|c|c|c|}
\hline \multicolumn{5}{|c|}{ Current Efficiency } \\
\hline & Boric acid (0,025M) & HF (0,025M) & Boric acid (0,05M) & HF (0,05M) \\
\hline \hline $10 \mathrm{~V}$ & 0,88328 & 0,99179 & 0,960025 & 0,938402 \\
\hline $7,5 \mathrm{~V}$ & 0,99807 & 0,969363 & 0,940056 & 0,962072 \\
\hline $5 \mathrm{~V}$ & 0,96915 & 0,985128 & 0,922401 & 0,967055 \\
\hline
\end{tabular}

the 0.05 M HF study can be applied maximum $10 \mathrm{~V}$, at the $0.05 \mathrm{M}$ boric acid study can be applied maximum 15 volt.

Current efficiency was calculated using the following equation. Starting from Faraday's law M theoretically was calculated.

$M_{\text {theoretically: the mass of the substance liberated at an }}$ electrode in grams.

M: molecular weight $(\mathrm{g})$

$\mathrm{n}$ : valence effect

i: current (amperes)

$\mathrm{t}$ : time (sec)

F: faraday constant 96485 As / eg.

Current efficiency was calculated as the ratio actual value and theoretical value. The obtained values were shown in Table 2.

\section{CONCLUSION}

Despite, working conditions and using membrane were same, because of different charges and different molecular diameters $\mathrm{F}^{-}$and $\mathrm{B}_{3} \mathrm{O}_{4}{ }^{=}$ions were need different driving forces. Because of $\mathrm{F}^{-}$ionic strength greater than $\mathrm{B}_{3} \mathrm{O}_{4}{ }^{2}$, hydrofluoric acid production was needed less energy consumption more than boric acid. And fluorine ion diameter is smaller than the diameter of borate ions, fluorine ions passing through the membrane pores were more rapid than $\mathrm{B}_{3} \mathrm{O}_{4}{ }^{=}$ions, Figure $\mathbf{4}$ good example for this situation.

This results in a growing demand for alternative process solutions such as Electro dialysis with Bipolar Membranes (EDBPM). These must be simultaneously economically attractive and have a low impact on the environment.

Over-voltage application was caused separation anion and cation exchange layers of bipolar membrane from each other. In the industrial sense BPM processes, despite in this process acid and base can be obtained pure and in one step, it was required after concentrated study. Because the virulent acid was processed in this process wasn't concentrate. Using anion exchange and cation exchange membranes together bipolar membranes can be improved process which has high energy efficiency and low investment costs. 


\section{REFERENCES}

[1] Bauer B, Gerner FJ, Strathmann H. Development of bipolar membranes. Desalination 1988; 68: 279-292. http://dx.doi.org/10.1016/0011-9164(88)80061-4

[2] Bailly M. Production of organic acids by bipolar electrodialysis: Realizations And Perspectives. Desalination 2002; 144: 157-162.

http://dx.doi.org/10.1016/S0011-9164(02)00305-3

[3] Roux-de Balmann H, Bailly M, Lutin F, Aimar P. Modelling of the conversion of weak organic acids by bipolar membrane electro dialysis. Desalination 2002; 149: 399-404. http://dx.doi.org/10.1016/S0011-9164(02)00863-9

[4] Wang $\mathrm{Y}$, Huang $\mathrm{C}, \mathrm{Xu} \mathrm{T}$. Which is more competitive for production of organic acids, ion-exchange or electrodialysis with bipolar membranes? J Membr Sci 2011; 374: 150-156. http://dx.doi.org/10.1016/j.memsci.2011.03.026

[5] Wang $\mathrm{Y}$, Zhang $\mathrm{X}, \mathrm{Xu} \mathrm{T}$. Integration of conventional electro dialysis and Electro dialysis with bipolar membranes for production of organic acids. J Membr Sci 2010; 365: 294301 http://dx.doi.org/10.1016/i.memsci.2010.09.018

Wang $X$, Wang $Y$, Zhang $X, X u ~ T$. Insitu combination of fermentation and electro dialysis with bipolar membranes for the production of lactic acid: operational compatibility and uniformity. Bioresour Technol 2012; 125: 165-171. http://dx.doi.org/10.1016/j.biortech.2012.08.125

[7] Novalic S, Okwor J, Kulbe KD. The Characteristics of Citric acid separation using electrodialysis with bipolar membranes. Desalination 1996; 105: 277-282. http://dx.doi.org/10.1016/0011-9164(96)00083-5

[8] Pinacci P, Radaelli M. Recovery of citric acid from fermentation broths by Electro dialysis with bipolar membranes. Desalination 2002; 148: 177-179. http://dx.doi.org/10.1016/S0011-9164(02)00674-4

[9] Tongwen $X$, Weihua $Y$. Citric acid production by electro dialysis with bipolar membranes. Chem Eng Process 2002; 41: $519-524$ http://dx.doi.org/10.1016/S0255-2701(01)00175-1

[10] Tongwen $X$, Weihua $Y$. Effect of cell configurations on the performance of citric acid production by a bipolar membrane electro dialysis. J Membr Sci 2002; 203: 145-153. http://dx.doi.org/10.1016/S0376-7388(01)00795-5

[11] Yu L, Guo Q, Hao J, Jiang W. Recovery of acetic acid from dilute waste water by means of bipolar membrane electrodialysis. Desalination 2000; 129: 283-288. http://dx.doi.org/10.1016/S0011-9164(00)00068-0

[12] Zhang X, Li C, Wang Y, Luo J, Xu T. Recovery of acetic acid from simulated Acetaldehyde waste waters: bipolar membrane electro dialysis process sand membrane selection. J Membr Sci 2011; 379: 184-190.

http://dx.doi.org/10.1016/j.memsci.2011.05.059

[13] Ali MAB, Rakib M, Laborie S, Viers P, Durand G. Coupling of bipolar membrane electrodialysis and ammonia stripping for direct treatment of Waste waters containing ammonium nitrate. J Membr Sci 2004; 244: 89-96.

http://dx.doi.org/10.1016/j.memsci.2004.07.007

[14] Wei $Y$, Wang $Y$, Zhang $X, X u ~ T$. Treatment of simulated brominate dbutyl rubber waste water by bipolar membrane electrodialysis. Sep Purif Technol 2011; 80: 196-201. http://dx.doi.org/10.1016/j.seppur.2011.04.003

[15] Badruzzaman M, Oppenheimer J, Adham S, Kumar M. Innovative beneficial reuse of reverse osmosis concentrate using bipolar membrane electro dialysis and electro chlorination processes. J Membr Sci 2009; 326: 392-399. http://dx.doi.org/10.1016/j.memsci.2008.10.018

[16] Lameloise M-L, Lewandowski R. Recovering L-malic acid from a beverage industry waste water: experimental study of the conversion stage using bipolar membrane electro dialysis. J Membr Sci 2012; 403-404: 196-202.

http://dx.doi.org/10.1016/j.memsci.2012.02.053

[17] lizuka $A$, Hashimoto $K$, Nagasawa $H$, Kumagai $K$, Yanagisawa $\mathrm{Y}$, Yamasaki A. Carbon dioxide recovery from carbonate solutions using bipolar membrane electro dialysis. Sep Purif Technol 2012; 101: 49-59.

http://dx.doi.org/10.1016/j.seppur.2012.09.016

[18] Vera E, Sandeaux J, Persin F, Pourcelly G, Dornier M, Ruales J. Deacidification of passion fruit juice by electrodialysis with bipolar membrane after different pretreatments. J Food Eng 2009; 90: 67-73. http://dx.doi.org/10.1016/i.jfoodeng.2008.06.003

[19] Quoc AL, Mondor M, Lamarche F, Makhlouf J. Optimization of electrodialysis with bipolar membranes applied to cloudy apple juice: minimization of malic acid and sugar losses. Innov Food Sci Emerg Technol 2011; 12: 45-49. http://dx.doi.org/10.1016/j.ifset.2010.12.007

[20] Trivedi GS, Shan BG, Adhikary SK, Indusekhar VK Rangarajan R. Studies on bipolar membranes part II: conversion of sodium acetate to acetic acid and sodium hydroxide. React Funct Polym 1997; 32: 209-215. http://dx.doi.org/10.1016/S1381-5148(96)00088-0

[21] Novalic S, Kongbangkerd T, Kulbe KD. Separation of gluconate with conventional and bipolar electrodialysis. Desalination 1997; 114: 45-50. http://dx.doi.org/10.1016/S0011-9164(97)00153-7

[22] Bailly M. Production of organic acids by bipolar electrodialysis: realizations and perspectives Desalination 2002; 144: 157-162. http://dx.doi.org/10.1016/S0011-9164(02)00305-3

[23] Trivedi GS, Shah BG, Adhikary SK, Rangarajan R. Studies on bipolar membranes part III: conversion of sodium phosphate to phosphoric acid and sodium hydroxide. React Funct Polym 1999; 39: 91-97.

http://dx.doi.org/10.1016/S1381-5148(97)00159-4

[24] Luo GS, Pan S, Liu JG. Use of the electrodialysis process to concentrate a formic acid solution. Desalination 2002; 150 : 227-234.

http://dx.doi.org/10.1016/S0011-9164(02)00978-5

[25] Nagarale RK, Gohil GS, Shahi VK, Trivedi GS, Thampy SK, Rangarajan R. Studies on transport properties of short chain aliphatic carboxylic acids in electrodialytic separation. Desalination 2005; 171(2): 195-204. http://dx.doi.org/10.1016/i.desal.2004.06.190

[26] Jaime Ferrer JS, Laborie S, Durand G, Rakib M. Formic acid regeneration by electromembrane processes. J Membr Sci 2006; 280: 509-516. http://dx.doi.org/10.1016/j.memsci.2006.02.012

[27] Lixin Y, Qinfeng G, Jihua H, Weijun J. Recovery of acetic acid from dilute wastewater by means of bipolar membrane electrodialysis. Desalination 2000; 129: 283-288. http://dx.doi.org/10.1016/S0011-9164(00)00068-0

[28] Bailly M, Roux-de Balmann H, Aimar P, Lutin F, Cheryan M. Production processes of fermented organic acids targeted around membrane operations: design of the concentration step by conventional electrodialysis. J Membr Sci 2001; 191: 129-142. http://dx.doi.org/10.1016/S0376-7388(01)00459-8

[29] Strathmann H, Bauer B, Rapp HJ. Better bipolar membranes. Chemtech 1993; 17-24.

[30] Jaime-Ferrer JS, Couallier E, Viers Ph, Durand G, Rakib M. Three-compartment bipolar membrane electrodialysis for splitting of sodium formate into formic acid and sodium hydroxide: Role of diffusion of molecular acid. J Membr Sci 2008; 325: 528-536.

\section{http://dx.doi.org/10.1016/j.memsci.2008.07.059}

[31] Alcaraz A, Ramírez P, Manzanares JA, Mafé S. Conductive andv Capacitive Properties of the Bipolar Membrane Junction 
Studied by AC Impedance Spectroscopy. J Phys Chem 2001; 105(47): 11669-11677. http://dx.doi.org/10.1021/jp011581x

[32] Strathmann H. Electrodialytic Membrane Processes and Their Practical Application, Studies in Environmental Science 59. Environmental Oriented Electrochemistry, C.A.C. Sequeira (Ed.), Elsevier Science, Amsterdam 1994; pp. 495533.
[33] Kattan Readi OM, Kuenen HJ, Zwijnenberg HJ, Nijmeijer K. Novel membrane concept for internal $\mathrm{pH}$ control in electrodialysis of amino acids using a segmented bipolar membrane (sBPM). J Membr Sci 2013; 443: 219-226. http://dx.doi.org/10.1016/j.memsci.2013.04.045 